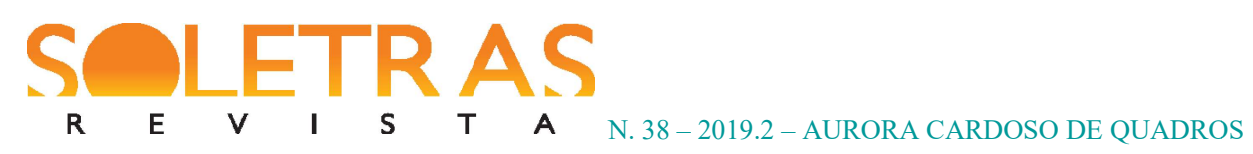

\title{
Reconstrução dilacerada: memórias de um proscrito
}

\author{
Aurora Cardoso de Quadros ${ }^{1}$
}

\begin{abstract}
Resumo: Este artigo, com o apoio das elaborações do Stuart Hall sobre Diáspora, tem como objetivo analisar a associação entre a estética e a vida no exílio de Ferreira Gullar, trazendo ao centro o Poema Sujo, publicado em 1976. O momento da criação, que representa a busca do passado, situa-se num período de forte tensão, devido ao recrudescimento dos assédios do Brasil, então sob o regime militar. No impulso de deixar um testemunho da sua vida, acreditando aproveitar desse modo o tempo restante, os versos buscam reconstruir, pela palavra poética, o tempo, a vida e o espaço do proscrito. Observa-se que, ao representar sua trajetória pela arte da palavra, ele escreve a História antagônica que vive. Essa associação entre Poesia e Vida cria, no caso de Gullar, uma configuração que reforça o sentimento advindo da diáspora, pois, ao revolver sua vida, remodela os modos de dizê-la como reflexo do espírito de revolta de que se acomete. A linguagem fortalece o proposital impacto estético, e esse procedimento fortalece o enfrentamento ideológico, em radical contraposição ao conservadorismo.
\end{abstract}

Palavras-chave: Poema sujo. Diáspora. História. Rebeldia.

\section{O poema, a História e a memória diaspórica}

Na obra de Ferreira Gullar publicada em 1976 e intitulada Poema sujo (GULLAR, 2013), há uma expressa volta ao passado, numa tentativa de recompor a trajetória do autor em um momento crucial da sua vida. Os versos investem na representação do eu no mundo e, no afã de abarcar a história vivida, Gullar retoma um passado que, ao final das contas, equaciona a busca de si mesmo. Ao examinar-se, situa-se em tempo e espaço, nos âmbitos físico e psicológico, envolvendo o corpo carnal, que busca as experiências corpóreas; o corpo mnemônico, que busca o elo escondido entre o seu hoje e o início de tudo; e o corpo político, que reflete sobre seus fazeres sociais, sua cultura e sua construção emocional mediante relações, sentimentos, ideias, fatos e tendências políticas. No ser isolado e incompreendido as múltiplas faces se despedaçam e se aglutinam:

\footnotetext{
${ }^{1}$ Doutora em Teoria Literária e Literatura Comparada pela Universidade de São Paulo. Atua como professora do Departamento de Comunicação e Letras da Universidade Estadual de Montes Claros, na área de Estudos Literários. Minas Gerais, Brasil. E-mail: auroracardoso2010@hotmail.com (i) https://orcid.org/0000-0002$\underline{0511-2090}$
} 
corpo meu corpo-falo

insondável incompreendido meu cão doméstico meu dono cheio de flor e de sono

meu corpo-galáxia aberto a tudo cheio de tudo como um monturo

de trapos sujos latas velhas colchões usados sinfonias sambas e frevos azuis de Fra Angelico verdes de Cézanne matéria-sonho de Volpi

Mas sobretudo meu

corpo nordestino

mais que isso maranhense mais que isso são-luisense mais que isso

ferreirense newtoniense alzirense [...] (GULLAR, 2013, p. 40)

Além dos aspectos culturais e fisiológicos que se convergem no corpo, esse se mescla do prosélito, criando um ser que se multiplica para se apreender em sua unidade, marcada pelo deslocamento do espaço e pelo reposicionamento ideológico. Nesse duplo de homem e mundo, um polo é representado em possibilidades e potencial. O componente político antecede o elemento poético, ainda latente:

pelo meu carneiro manso

por minha cidade azul

pelo Brasil salve salve

Stalingrado resiste.

A cada nova manhã

nas janelas nas esquinas na manchete dos jornais

Mas a poesia não existia ainda (GULLAR, 2013, p. 36). 
Os motivos da escrita do Poema sujo, conta o poeta na apresentação da obra, teriam origem no período em que o cerco da ditadura militar se fecha, e o perigo de ser pego e morto na Argentina, onde estava como exilado político, impulsiona-o a escrever, conforme suas palavras, "a massa da experiência vivida - lançar o passado sobre o papel e, a partir desse magma, construir o poema que encerraria minha aventura biográfica e literária" (GULLAR, 2013, p. 11). Representa, dessa maneira, um panorama de sentimentos, vivências, lembranças, posicionamentos e circunstâncias envolvidas nas decorrências da diáspora de vários brasileiros na época. Compulsoriamente pela situação, Gullar se vê como arrancado do seu lugar, das suas relações, o que tangencia a anterior situação e motiva um questionamento semelhante ao do Stuart Hall sobre a imigração dos caribenhos na Inglaterra, cuja questão '[c]omo imaginar sua relação com a terra de origem, a natureza de seu "pertencimento"?' (HALL, 2006, p. 26), pode, no caso de Gullar, ser perquirida com a participação das vozes dos seus "eus".

No contexto de então, o Poema Sujo, nas representações que carregam reflexos do sujeito em si e no mundo vivido, veicula valores e tendências, entrecruzando estética e vida, pensamento e cultura, estilo e atitude. Segundo Alfredo Bosi (2002), "O Poema sujo é uma longa fala da memória, e o seu objeto, real e imaginário, a cidade do poeta, São Luiz do Maranhão. Memória-saudade e memória desespero” (BOSI, 2002, p. 473). Em 1999, quando escreve “A nova concepção da morte” (GULLAR, 2006), bem revela o estado do presságio que diante dele se afigurou naquele momento de tensão, e os versos duais sobre a morte permitem o diálogo com o que vivera nesse tempo sofrido de exílio e evidencia a angústia da constatação da transitoriedade da vida. A ideia da finitude inquieta a alma, que reflete sobre a morte no momento em que isso se obriga:

\author{
Mas, se vinda de dentro ou de fora, não se altera \\ essencialmente o fato: a morte, por si, gera \\ um processo que altera as relações de espaço \\ e tempo e modifica, inverte, em descompasso (GULLAR, 2006, p. 247)
}

O que ecoa na substância histórica do Poema sujo pode ser visto sob o ângulo de entendimento da premissa simbiótica que se integra àquela segundo a qual, ainda que seja um produto social, uma obra é acima de tudo um produto literário. Ainda que a literatura seja acima de tudo o como se diz, torna-se profícuo, para se contornar a essência do referido 


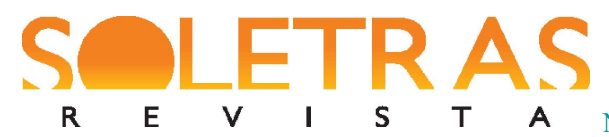

N. 38 - 2019.2 - AURORA CARDOSO DE QUADROS

poema, detalhar fatores que evidenciam a manifesta interação com a diáspora na literatura de Gullar, não apenas em Poema sujo, mas em muitas das suas construções.

Ao analisarmos, por exemplo, os versos do poema “Açúcar” (GULLAR, 2004, p. 76), notamos que o "enredo" da composição está inserido numa realidade social que ultrapassa o âmbito da subjetividade poética, do ambiente lírico e ficcional, mas que se constitui num espaço de isolamento e angústia. A figura marginal do lavrador de cana de açúcar é construída pela tensão que o julga em seu exílio social, em seu canto de passiva miséria e sofrimento, na vida que se torna curta devido à sua precariedade. Juntamente com a representação de uma tomada de consciência do eu, que expressa a angústia das implicações sociais de degustar um doce café, traz à luz fatos ocultos acerca do açúcar como produto do sistema capitalista, que camufla as implicações ideológicas:

O branco açúcar que adoçará meu café

Nesta manhã de Ipanema

Não foi produzido por mim

Nem surgiu dentro do açucareiro por milagre. (GULLAR, 2004, p. 76),

O procedimento explicita o mundo exterior e seus problemas, sensibilizando o âmago do "eu", certamente reflexo do intelectual. Os problemas, no caso, a desigualdade, o capitalismo, a injustiça e a desvalorização do trabalho do homem simples são tomados em forma de sensibilização a respeito do seu próprio privilégio em detrimento daquele que sofreu para propiciá-lo. Ao contrário do poema "sujo", nesses versos o ser posiciona-se em vantagem material, mas angustia-se com essa vantagem, puxando a escala do conforto para a reflexão moral e tornando-a elemento negativo. Ambos os polos da expressão poética tornam-se marginais de um centro ideal, sendo que o abastado reproduz o sistema e se revela em íntimo embate por isso. E a poesia que emana do seu posicionamento revela-se explicitamente também inserida conscientemente nesse status quo do qual participa e, ao mesmo tempo, exclui-se pela sensibilização. O sujeito por trás dos versos, de certo modo, seu criador, pode ser imaginado como um ser inserido em um contexto cujos elementos convergem na construção do que se entende por identidade. Na acepção de Zygmunt Bauman, segundo a qual a identidade "nasceu da crise do pertencimento e do esforço que esta desencadeou no sentido de transpor a brecha entre o "deve" e o "é" e erguer a realidade ao nível dos padrões estabelecidos pela ideia - recriar a realidade à semelhança da ideia" (BAUMAN, 2005, p. 26). 


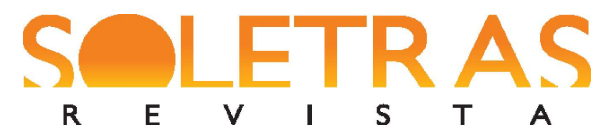

E esse estado de coisas expresso pelo "eu" de "Açúcar", esse mundo fora de si, serve para expressar o que vai dentro de si: um âmago privilegiado que usufrui do trabalho árduo do trabalhador e muito pouco poder fazer pela mudança. Neste caso, ocorre o oposto do que ocorre com o "eu” do Poema Sujo, em que o ser está fora do seu canto, do lugar a que se sente pertencer, mas que, em circunstâncias diferentes, renega esse mesmo espaço desejado, devido aos fatos que o fizeram amargurado, rejeita seu lugar pelo que se tornou por causa desse mesmo lugar amado. E, pensando na dicotomia entre poesia e prosa, proposta por René Welleck e Austin Warren (1976), segundo os quais a poesia reflete, em primazia, o mundo interior, e a prosa, o mundo exterior, os versos delimitam novos modos poéticos de ser e de enxergar a si e ao mundo. Busca, para reverberar sua alma excluída e arremessada para fora do seu lugar, além de ameaçada pelo fim eminente, as palavras que a identificam no momento. A mente agônica e em estado de alerta busca a memória imersa de si. Em movimento inverso e correspondente, busca reapresentar, em uma dinâmica de remontar o mundo exterior, revendo-se em meio a fezes, a memórias de vaginas, frutas podres, pensamentos cortantes; ideais que poderiam ter sido transplantados, mas que não foram, sendo que um e outro (âmbito interior e mundo) se ligam numa interação: harmônica em natureza, mas conflitante em sentimento. Revelam com isso a influência mútua entre literatura e cultura, literatura e história; revelando também as virtualidades da questão da identidade.

A ficção da identidade revelada por Stuart Hall (2002) parece ser reconstruída na ficcionalidade poética, ligada a fatos biográficos do sujeito que, vivenciando a extirpação obrigada pela ditadura, é influenciado por esse contexto que, por assim dizer, "insere-o em exclusão". E esse mesmo sujeito, além de ser levado a agir, menos que reagir, a pensar os fatos que vivencia também atua de modo a criar sugestões de identidade com respeito aos valores e posicionamentos que veicula. Como poeta, revela esses processos atitudinais da criação, que se aliam ao ser político e social, que agora se constrói pelo signo da desconstrução. Ao se ver envolvido em uma tentativa de forçosa desconstrução, revolta-se e retoma o que seria o passado individual e social construído até ali. Esse modo de associar o indivíduo e o mundo na poética é recorrente na obra de Gullar. São variados os sentidos implícitos que se associam nos versos de Gullar, de modo geral, para dar unidade do ser em sua multiplicidade cultural. Um dos aspectos sociais dos versos de "Açúcar”, por exemplo, é a ideologia e sua negação, o que se associa à poesia para edificar ideais e motivações emocionais. Eles tornam-se, portanto, exemplares de que a literatura, veiculando valores de 


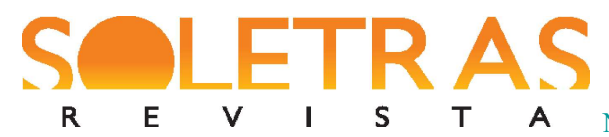

N. 38 - 2019.2 - AURORA CARDOSO DE QUADROS

práticas vigentes nas relações sociais, torna-se contra ideológica, no sentido de ir contra o discurso naturalizado do poder, quando esse nega ao homem a liberdade de emancipar-se e o posiciona onde for conveniente à sua manutenção. Ao denunciar o fato pela poesia, Gullar envolve e conscientiza ao mesmo tempo, chamando a atenção para os fatores que tornam homens opressores e oprimidos. E a face libertária que os versos constroem é capaz de promover o resultado dos vários funcionamentos que Candido (1999) apresenta como atuação da literatura, sendo que os versos, de certo modo, têm o potencial de atuar de modo abstrato e subliminar da formação humana. Isso porque oportuniza a reflexão sobre os implícitos que provocam as injustiças e a incapacidade de lidar com as diferenças.

Além disso, a questão da exclusão é trazida de modo crítico, e o resultado é o entendimento de que versos como os referidos seriam, do mesmo modo que os romances, representativos de "fatos eminentemente associativos; obras e atitudes que exprimem certas relações dos homens entre si, e que, tomadas em seu conjunto, representam uma socialização dos seus impulsos íntimos" (CANDIDO, 2000, p. 127). As figuras dos "personagens" do poema "Açúcar" (o privilegiado e o lavrador) representam a desigualdade, a injustiça, a opressão do mesmo modo que o regime de então representa a opressão para o exilado, o poeta Ferreira Gullar. Sua crítica subjacente, devido à sensibilização que propicia, pela flexibilidade proposta pelo olhar do próprio ser privilegiado e pela expressão do ser perseguido, tem um sentido de fortalecimento da emancipação do homem, tornando-se contraideológica. O modo como o poeta se expressa torna bela a ideia. Cria-se, assim, "a aliança verdadeiramente nupcial de sujeito e objeto, que só se realiza quando a alma consegue objetivar-se na mesma medida em que a história consegue subjetivar-se entre os ritmos e as figuras da linguagem" (BOSI, 2004, p.10). Isso tudo é dito para fundamentar a ideia de que a subjetivação da história de proscrição do ser poético nos versos de Gullar representam tanto o ser poético quanto o ser político, e que o efeito da poesia modifica o olhar sobre a História. Proscrição.

\section{O Poema Sujo em diálogo}

Se a análise sociológica de "Açúcar" permite desvelar as representações políticas e sociais e contribuir para uma reflexão crítica sobre estas, inclusive na atuação que exercem sobre as representações dos sujeitos, banidos ou não, o Poema sujo confirma o desvelamento 
e o reflexo da mente que pensa o operário da cana-de-açúcar, em sua experiência comunista que, em princípio, acredita ser a solução para, de certo modo, reintegrar aqueles seres ignorados pelo grupo dominante. Isso corrobora e confirma na obra literária reflexos do mundo, o que a torna o resultado de vários fatores que envolvem o contexto histórico, os valores que incluem ou excluem e as relações sociais das quais sua poética resulta. Ainda que as metáforas aparentem um sentido simples, cotidiano, percebe-se sua profundidade com os elos externos, que muitas vezes revelam as diferenças sociais, como ao tratar das várias maneiras de a noite acontecer, centrando-se na "noite proletária":

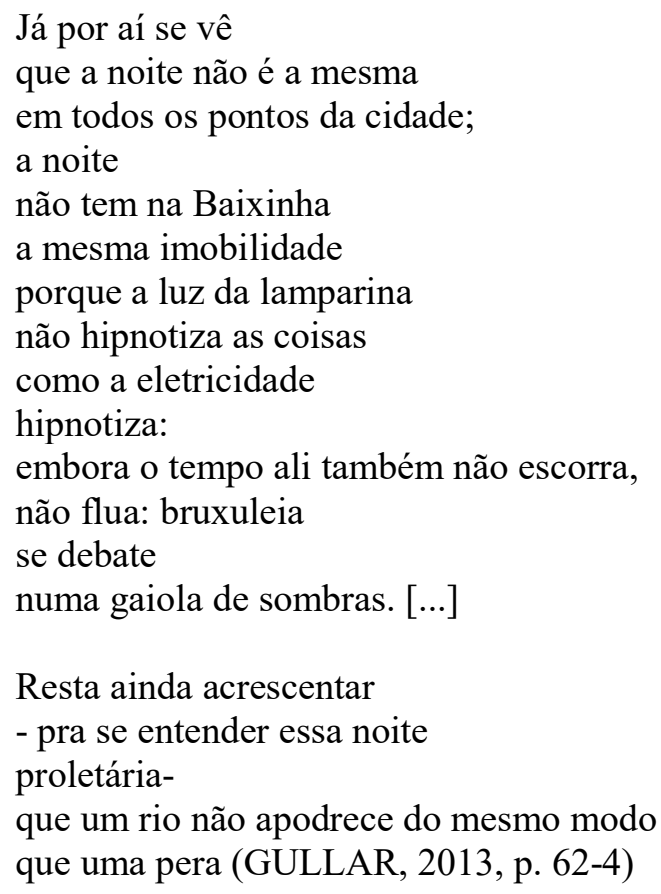

Aí está a essência da poética de Gullar: o texto esteticamente singular sendo ponderado a partir das suas implicações históricas e culturais. E, se em "Açúcar" e em outros poemas sua dialética se dá pela negação, que dirá da construção em que a negação se instala na própria linguagem, como em Poema Sujo, em que ele utiliza os termos baixos para se referir aos órgãos genitais, em que ele insere fezes, maus cheiros, o podre o e o asqueroso. Ao tratar da chocante conjuntura do país e da própria vida, ele também choca pela linguagem, delineando-a com a natureza da marginalidade e jogando-a como forte candidata ao banimento do conservadorismo. Bosi (2003) enquadra a obra Poema sujo na fase madura do intelectual, após 64, quando esse, segundo o crítico, está mais capacitado a entender o seu espaço e o seu tempo: 
trata-se de ver mais concretamente a História, a julgar mais criticamente o próprio lugar do poeta na trama da sociedade, refletir mais dramaticamente a condição do homem brasileiro e do homem latino-americano sem medusarse no fetiche abstrato, no fundo e gótico, do "homem" em geral. (BOSI, 2003, p. 173).

Já João Luiz Lafetá entende a negação pela linguagem e a contestação do seu uso habitual como a grande qualidade dos poemas de Gullar, uma vez que "negando a retórica, a eloquência, a facilidade das imagens, eles se destacam da massa anódina de textos da sua época" (LAFETÁ, 2004, p.154). Pode-se, desse modo, entender em sua proposta a ponderação da atitude de se indignar, usando como vocabulário as metáforas fortes, as cenas íntimas, com a racionalidade de olhar além das aparências, de se buscar entender motivações e mensagens. Talvez isso torne o teor estético imbuído de maior força, o leitor mais consciente e envolvido, e a literatura mais acessível a todas as mentalidades no curso da História.

A potência da dialética de Gullar, que constrói o diálogo entre o "eu" e o mundo, ainda que um mundo negado, não precisa explicitar os sentidos daquilo que se apresenta oculto, mesmo no que escancara. $\mathrm{O}$ entendimento da sua poesia se insinua no acordo entre intuição atada aos fatos corpóreos, sejam eles localizados no corpo do Brasil da linha dura, na América Latina, em São Luís, a cidade natal, nos fundos da casa da infância, na cozinha, na sala de jantar, na quitanda do pai. O âmbito psicológico apresenta elementos que enquadram o eu como ser consciente do seu corpo e do seu entorno, fazendo dialogar os polos interior e exterior ao eu. Revela-se a dialética do indivíduo que reflete sobre seu ser e sobre seu corpo, sem negligenciar o outro. Essa veia social pode-se pressentir, ainda mesmo nas elaborações do mundo interior do "eu".

Como no poema "Traduzir-se" (LAFETÁ, 2004, p. 114-15), em que o eu se apresenta duplo, sendo que uma metade é "Todo mundo" e "Outra parte é ninguém”, a configuração do Poema sujo volta-se para um sujeito, que se reverbera em partes distintas. A "arte", que, em "Traduzir-se", ao final, soluciona-se na tradução de ambas as partes do "eu", em Poema sujo soluciona, pelo ato de registrar sua memória, o ser cultural, político, seu mundo e sua história. A legibilidade de Poema Sujo, na busca do tempo, se comparado à obra de Proust, que, segundo Augusto Meyer "é a reconquista do eu que se perdeu” (MEYER, 1958, p. 150), em 
Gullar, é a retomada agônica do que se viveu. Na condensação do ser poético, histórico e político, que se expressa em prosélito e poesia, verifica-se que:

\begin{abstract}
Esse adensamento - sinônimo hegeliano do processo que leva ao concreto permitiu que o autor de Poema sujo alcançasse uma dimensão coral sem por isso perder o calor daqueles afetos singularíssimos que só as imagens da sua cidade São Luís seriam capazes de provocar. A superação do surrealismo juvenil atravessou um purgatório brechtiano programado (alguns poemas abertamente didáticos e o tom geral de Dentro da noite veloz (1975) para conquistar uma nova poética na qual memória e crítica não se pejam de dar as mãos" (BOSI, 2003, p. 174).
\end{abstract}

A construção poética se dá de modo a elidir a obra inventiva juntamente com a vida real, que exprime o encadear da visão sobre si, em sua história, e a visão sobre a História, em seu contexto. Também, ao se manifestar como um ser que olha para si e vê aquele que olha para o outro, até mesmo em situações cotidianas, domiciliares, constrói sua forma de participação de intelectual sensível, representando ambos os espaços: psíquico e histórico; ambos os corpos: físico e social, que transitam entre o universal e o particular pela veia poética.

Este fato torna-se auxiliar para refletir sobre o que os versos representam e/ou ocultam, sua influência exercida e ao mesmo tempo recebida da experiência e da atuação do poeta ou do eu, caso se prefira, na realidade social. Outro aspecto simbiótico (histórico e estético) dos versos da sua poética é que esta tem a potencialidade de, elucidando a realidade, trazer aspectos culturais, numa carga expressiva que varia entre o chocante e o enternecedor. Ratifica-se que, uma vez que a percepção e a crítica do seu conteúdo político e social confluem para a sua configuração intelectual e cultural, essa tendência não deixa muito a desejar com relação ao aspecto formal, que se apresenta aliada cooperativamente ao ingrediente histórico e cultural. E, no que tange a expressividade da linguagem, as propriedades intrínsecas do Poema sujo se distinguem de tantos outros do autor devido a maior presença de expressões obscenas muitas delas, se tomadas pelo senso comum, fortemente marginais, referentes a passagens da sua vida, aos cantos escondidos da primeira experiência sexual, que são descritos com os nomes vulgares dos órgãos genitais, dos cheiros de fezes, dos espaços menos propícios dessas ocorrências, como em meio aos dejetos do galinheiro. 
Muito embora a abordagem explícita traga uma estupefação inicial, suas pinceladas acabam por ir se adequando aos ares e aos sentidos do poema como um todo. Talvez o fator contextual que qualifica essa linguagem licenciosa de dizer institua convergência com o clima geral do poema, exatamente pelas circunstâncias da sua criação. O leitor sente recender os cheiros, exalados em nebulosas na mente do eu, em todo o seu percurso, mesmo que esteja suspenso num segundo plano. Nesse procedimento, além do efeito estético, que pode parecer antiestético para muitos, podem residir traços do seu trajeto que se ajustam à dialética de vida e arte, e na "secreta coerência de seus motivos, imagens e afetos, ou nos cortes e nas descontinuidades com que a sua poesia acompanhou a vida brasileira na segunda metade do século XX" (BOSI, 2002, p. 171). Mostrar a vida como ele a vê, ou pelo menos tornar a palavra o mais condizente possível com esse modo de ver, no seu âmbito mais íntimo e real, pode supor um caminho de compreensão paralela ao que Benjamin (1987) diz sobre a vida real e seus objetos, em comparação com a representação artística, quando se deseja a superação da alienação:

Somente a superação daquelas esferas compartimentalizadas de competência no processo da produção intelectual, que a concepção burguesa considera fundamentais, transforma essa produção em algo de politicamente válido; além disso, as barreiras de competência entre as duas forças produtivas - a material e a intelectual, erigidas para separá-las precisam ser derrubadas conjuntamente. (BENJAMIN, 1987, p. 129).

No ato de rememorar, a fluência psíquica, numa refração desordenadamente intuitiva lança o foco em ideias, acontecimentos, coisas, percepções, utilizando-se de uma linguagem que articula os sentidos. As coisas da quitanda do pai, os cenários de São Luís, além dos outros locais em que habitou. São constantes os definidores de excrementos, de sujeira e devassidão.

Nessas configurações, a busca de entendimento sobre o efeito estético pode variar, mas a compreensão do seu teor ideológico pode ser encontrada em vários pontos e na própria aura circunstancial do texto na época vivida sob a égide da linha dura da ditadura brasileira. Assim, a vertente crítica que se circunscreve à forma, ao modo da expressão, entrevê a vertente ideológica que esse modo de expressão também implica. Um estudo que calha bem à abordagem sobre o componente ideológico no dizer encontra-se no ponto de vista de BAKHTIN (1979), que considera o sujeito de todo discurso condicionado pela ideologia. Este 
autor fornece apoio teórico para explicar propriedades como as motivações, socialmente determinadas, no discurso presente nos versos de Gullar. Na revoltante situação em que se encontra nos anos de proscrito, o poeta reflete o "eu" e o outro. Anteriormente ao Poema Sujo, no poema intitulado "Maio 1964", ele havia exprimido:

Tenho 33 anos e uma gastrite. Amo

a vida

que é cheia de crianças, de flores

e mulheres, a vida,

esse direito de estar no mundo,

ter dois pés e duas mãos, uma cara

e a fome de tudo, a esperança.

Esse direito de todos

que nenhum ato

institucional ou constitucional

pode cassar ou legar.

Mas quantos amigos presos!

quantos em cárceres escuros

onde a tarde fede a urina e terror.

[...] (GULLAR, 2004, p. 81)

A inter-relação entre o aspecto estético e o social, no caso do poeta, corrobora o efeito emocional da expressão artística verbal, e o seu reflexo de realidade ocorre porque Gullar, enquanto autor, e sua obra, enquanto produto do ser social, não se encontram isolados, mas em sociedade, revelando suas vivências individuais e coletivas, advindas da sua cultura, e suas tendências estéticas, construtoras do seu estilo individual e da sua participação do sistema literário no período. Esse entendimento começa por definir a literatura não apenas como a obra literária em si, nem apenas como um mero reflexo da sociedade, mas a concebe numa relação dialética entre ambas acepções. Havendo o diálogo entre o leitor e a obra, e esta se concretizando em sua leitura, o efeito estético está emendado do teor histórico, fortalecendo seu efeito devido a carga emocional do período. E como são inúmeros os leitores, serão várias as interpretações e as maneiras de apreender subjetivamente os sentidos e valores contidos na obra, sejam estéticos, culturais ou, mais precisamente sociopolíticos. Pelo ethos do poeta, a política parece andar ao lado, e um texto literário sem objetivo especificamente político, por exemplo, pode se tornar, especialmente em se tratando de Gullar, um texto político. E a compreensão do meio social sob o qual vive o autor e no qual a sua obra é lida, às vezes, torna-se fundamental. 
É indiscutível que, na abordagem de uma obra poética, a relação entre o seu teor literário e os seus aspectos sociais, filosóficos, psicológicos, religiosos, culturais etc. se faz de modo complementar, ainda que numa hierarquia de prevalência do aspecto estético, para o qual os aspectos sociais são importantes, mas como subsídio de análise, interpretação e julgamento. No caso de Gullar, ambos os campos atraem análises que variam no enfoque dos sentidos filosóficos, psíquicos, político, culturais subjacentes. Pode haver, por exemplo, evocando a elaboração do pensamento marxista, a representação da relação dos homens com os bens em geral, de modo que a sociedade se configure como um sistema que produz seus indivíduos para o mercado, como é o caso do referido poema "Açúcar”, em que o amargo do suor do lavrador contrasta com a doçura do açúcar por ele produzido. Também em Poema Sujo, o operário se representa como ponto apologético do eu, tanto o "companheiro", alusivo às tendências políticas de então, quanto a cozinheira da casa, no fardo de serviço insalubre:

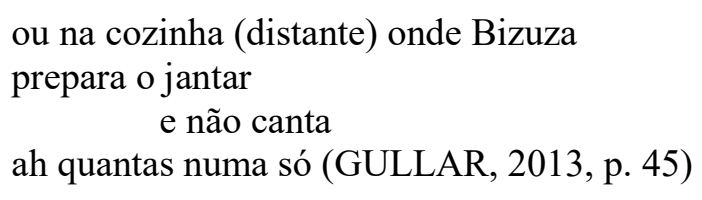

Esse é um detalhe em que o aspecto sociológico alia-se à sensibilidade que tonaliza a forma, criando um viés composto muito observado na poética de Gullar, em que as questões históricas e políticas são um dos traços da sua poesia. Entretanto, mesmo como mote e contexto do poeta destroçado que retoma em imagens sua vida, as questões ideológicas não são suficientes para construir um estigma limitante a um campo partidário uníssono, uma vez que nos versos "[h]á tanto dilaceramento nessa reconstrução febril do passado que, lido o poema de um só lance, cala-se toda veleidade de rotulá-lo ideologicamente” (BOSI, 2002, p. 143).

Forte também é o teor que sintoniza o local, o tempo e a memória, a partir do qual se viaja pelas cidades por onde transita, principalmente São Luís, a memória constante, cuja consciência é mantida em um plano psíquico associado a gavetas freudianas:

Bela bela

mais que bela

mas como era o nome dela?

$[\ldots]$

mudou de cara e cabelos mudou de olhos e risos mudou de casa 


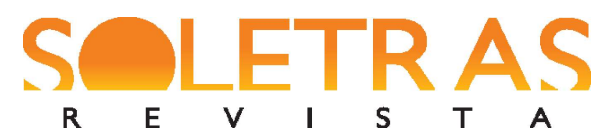

e de tempo: mas está comigo está

perdido comigo

teu nome

em alguma gaveta (GULLAR, 2013, p. 32)

$\mathrm{Na}$ topicalização espacial e temporal, o eu situa-se no presente e, embora revolva o tempo pretérito, quando vivia na capital maranhense; encontra-se exilado em Buenos Aires, onde física e temporalmente situa a gênese e o desenvolvimento do Poema Sujo, sob a égide das questões circunstanciais desse período do Brasil, que já ameaçava alcançar os fugitivos políticos. João Luiz Lafetá (2004), em seu estudo "Traduzir-se", no ponto em que coteja $A$ luta corporal e Poema sujo, privilegia o primeiro, da mesma opinião não compartilha Alfredo Bosi em "Roteiro do Poeta Ferreira Gullar" (BOSI, 2003). Lafetá considera que em Poema sujo o aspecto comunicativo prepondera ao aspecto meramente expressivo e individualista o que delinearia "a obrigatoriedade de escrever sempre destruindo" (p. 154). (LAFETÁ, 2004p. 154). Entende, com isso, que a justificação das obscenidades do poema é a miserável situação do homem e do país, a perseguição e a falta de liberdade de expressão, que provocara o sufoco intelectual, o ar irrespirável, infecto. E, não propriamente ao encontro radical da ideia de que a poética de Ferreira Gullar expressaria o "fascínio sensorial pelo feio, repulsivo e doentio" (AUERBACH, 1976, p. 448), atribuído ao poeta francês Baudelaire, pode-se entender que a poética do Poema sujo, por ser a representação de uma vida retomada, também expressa o clima em que é escrito. Ao construir sua escrita incluindo os assuntos, também proscritos como ele, além do sexo, expresso pelos termos baixos e carnais, referindo repetidamente aos órgãos genitais, inclui o asqueroso, o repugnante, que, como aconteceu com o poeta francês em seu gesto de rebeldia poética na sua ingrata Paris, protesta contra a sociedade e seu sistema político. A linguagem proibida de Gullar alia-se em espírito e efeito estético às inovações do escritor francês, cujo gosto e encantamento explicitam-se na obra Les Fleurs Du Mal: "Aux objets répugnants nous trouvons des appas" (BAUDELAIRE, 1964, p. 15), em que o poeta "maldito" apresenta a postura de achar encantos nas coisas repugnantes. Nesse destaque do elemento repulsivo em ambos, a ousadia da ruptura temática é expressa pela ousadia da ruptura vocabular e moralista. Entende-se que, com a referida ruptura, rompese idealmente com a comodidade da cultura e do conservadorismo daqueles tempos abjetos, evidenciando "um traço fundo da poética de Gullar: sua insistência na sujeira, na podridão, na degenerescência orgânica" (LAFETÁ, 2004, p. 211). 


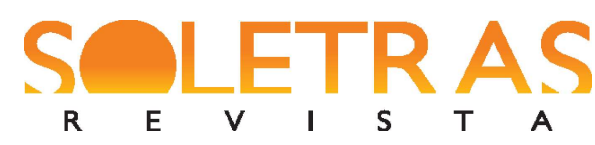

N. 38 - 2019.2 - AURORA CARDOSO DE QUADROS

Nesse sentido, o poema se constrói, não apenas como algo que o poeta pensa, nem como o que ele propriamente sente, mas, sobretudo, o que ele viveu e a partir daí suas implicações mnemônicas, sexuais, familiares, ideológicas, emocionais, centrando-se em tudo seu papel de poeta. Embora não radicalmente ideológicas, as palavras parecem, quando não cortar como faca, pelo menos incomodar o conservadorismo e apontar para o ideal de mudança e ataque dos revolucionários. A sensação de uma inteligibilidade, ainda que o efeito estético muitas vezes lembre a sobreposição cubista ou o surgimento de elementos sem relação lógica entre si do surrealismo, parece ser estabelecida a priori. E, de modo geral, percebe-se que há uma organicidade em torno da unidade antecipada, o intuito de retomar e fazer valer a experiência vivida. Mas o fato é que rompe e polemiza também a linguagem clássica, dita acadêmica e linear. E, como no cubismo que desloca as partes e as recompõe no todo, é possível uma leitura que já pressinta suas partes, ainda que nem sempre possivelmente alcançadas de modo a esgotar os sentidos. A explicação do poeta funcionando como a antecipação, completa-se com o título que, no caso de se entender como uma abstração temática, surreal, também completa uma certa ambientação ligada ao absurdo do regime, ao contrassenso da censura e repressão. A circunstância, a localização em espaço e tempo e o clima que envolverão os sentidos da leitura do poema começam por lembrar, num esboço, o panorama político de então: o caos. O caos mental busca a ideia para balizar as outras. A sensação é de que, se pudesse, naquele momento anterior à criação, concretizaria o seu mundo, fá-lo-ia palpável para verbalizá-lo. Isso porque, dependendo do que se deseja, talvez se explique pela ideia de Walter Benjamin, segundo a qual "a impressão digital de um assassino, na página de um livro, diz mais que o texto" (BENJAMIN, 1987, p. 128).

Naquele clima de repressão e despotismo, as imundícies do poema escrito em 1975 definem-se em contexto e na intenção de construir uma escrita que arremate a vida, de poeta e de homem, no suposto e terrível tempo que lhe restava. Os versos finais selam os iniciais, que haviam explicitado o conflito a perturbação no ato criador, que procura o dispositivo a partir do qual fluiria o poema. No prefácio do autor ele relata o que pensou no momento em que teve o impulso de escreve: "O poema deve começar antes de mim, pensei, começar antes do verbo." (GULLAR, 2013, P.11) Um paradoxo só possível pela arte da palavra, mas ao mesmo tempo presente naqueles tempos poucos distintos das representações surreais, a poesia procede a mimese de apresentar ao leitor, poeticamente, a falta de inspiração. É o modo, paradoxalmente muito inspirado e criativo de manifestar o problema que tem o escritor 


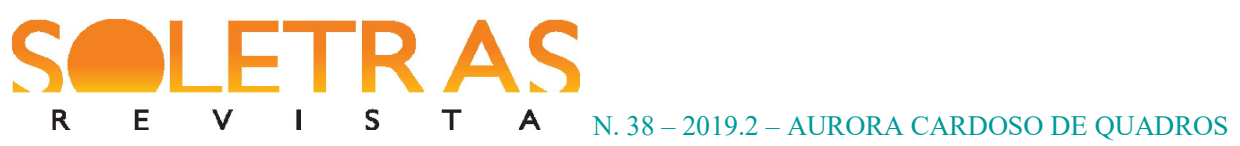

quando deve fazer despontar a palavra oculta. Esta aparece na manifestação contraditória da sua ausência. A situação, adjetivada de vertiginosa, torna-se um jogo entre confissão do caos e sua solução organizadora, uma vez que o caos se organiza ao se explicar. Da criação ainda não nascida, surge o nascimento ao dar à luz a expressão não nascida. $O$ contradito polissêmico e ambíguo parece ter o dom de extasiar. Esse efeito acontece pelo fato de,ao explicar a doída inexistência da inspiração verbal indispensável no ato criador, o indivíduo faz dessa lacuna, ao mesmo tempo, a solução para o início. Daí a inexistência, de modo concomitante, começar a existir pela solução expressiva da sua representação:

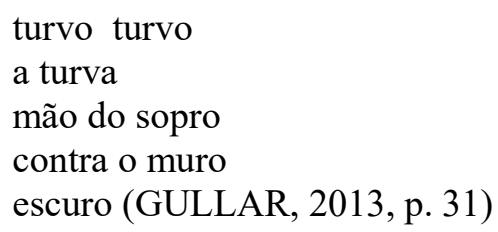

$\mathrm{Na}$ dialética que associa homem e mundo, poder-se-ia dizer que os versos iniciais se voltam à instância da origem, a origem da poesia, mas evidencia-se também a origem do ser. Ou melhor, o momento que antecede a origem do ser em formação, cuja passagem será contada, criando um primórdio anterior ao próprio princípio, que "era o verbo". Finalmente os fatos vão surgindo na memória. E esses momentos de metalinguagem sobre a criação são um dos pontos em que se centra o ângulo do "eu poeta", o ser que trabalha com a palavra. Esse sujeito que busca a vida, renegada socialmente e a ser resgatada pela escrita, encerra o percurso poético pela presença/ausência da cidade onde não pode estar, embora inevitavelmente esteja em vivência. Reafirma o paradoxo do desterro pela dialética entre o alheamento do lugar distante, que o separa e o extingue da sua terra, e a presença da cidade na memória:

a cidade está no homem quase como a árvore voa no pássaro que a deixa cada coisa está em outra de sua própria maneira e de maneira distinta de como está em si mesma

a cidade não está no homem 


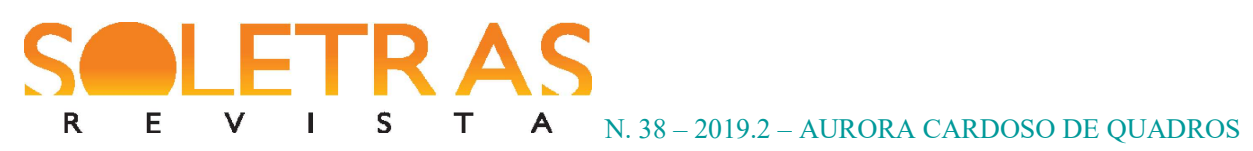

do mesmo modo que em suas

quitandas praças e ruas. (GULLAR, 2013, p. 100)

O panorama que se forma na trajetória da poesia diaspórica de Ferreira Gullar constrói-se na aliança da linguagem subjetiva com a existência histórica no mundo objetivo. Nessa existência do Poema sujo, a oscilação da memória que vasculha os tempos e as vivências movimenta o momento de expatriação compulsória do poeta, que se empenha em exprimir-se em corpo, alma e História. Revela-se o poeta um intelectual que critica as injustiças e os valores materiais, denunciando o "sangue humano nos legumes. Mundo sem voz, coisa opaca". (GULLAR, 20013, p. 36), enquanto representa sua inquietação ante a expiação histórica. João Luiz Lafetá (2004) explica esse incômodo arrazoando que:

a inquietude de Gullar faz parte, desde o começo, de um programa de procura de poesia. E de procura de realidade. Esse é o ponto-chave. Poeta sensível, ligado como poucos ao contexto cultural brasileiro, Ferreira Gullar está sempre buscando a linguagem mais adequada para exprimir-se e para exprimir, ao mesmo tempo, as nossas contradições sociais (LAFETÁ, 2004, p. 510).

Ao procurar na memória o tempo passado, Poema sujo cria um testemunho de vida, conforme seu objetivo declarado, antes que pela violência sua voz fosse calada. E, ao deixar o registro dos odores, dos sons, dos sujeitos e das experiências do passado, o que os justifica é a expulsão e o ponto limítrofe na vida do sujeito. O elemento degredado traz o repugnante para imprimir com força um posicionamento de protesto, segundo o qual, dependendo do que se deseja, "a impressão digital de um assassino, na página de um livro, diz mais que o texto" (BENJAMIN, 1987, p. 128).

\section{Considerações finais}

A tensão do degredo, representada pela estética dos versos lexicalmente agressivos rompem simbolicamente com o respeito indevido e acaba por revelar uma liberdade estética rebelde que, de certo modo, torna-se, por isso mesmo, contraponto da tensão ideológica. Também a linguagem obscena, que, em princípio parece constituir ponto de tensão, de certo modo, torna-se convergente ao que se espera do homem e do mundo, uma vez que se 
estabelece como instrumento de transformação, ao ferir e rebelar-se com o status quo do período da dita linha dura no Brasil. Funciona, desse modo, como revanche, instigando no espírito a resposta condizente com a tensão das circunstâncias vividas. Nessa trajetória os versos irão seguir no trilho da História, que se une como aliada em suas contradições e malogros. E, na forma com que constrói o poema, os versos se (des)ordenam por meio de sobreposições e refrações, aos moldes da memória, para onde o eu vai, passeia pelo lugar proibido e volta para o corpo presente. A história oculta de antes, revelando o menino em São Luís, cresce junto com ele, junto ao homem que se encontra numa retomada de si, do seu lugar do seu eu, da sua voz. Por fim, a mente agônica cuja memória busca o corpo e suas lembranças, ao reconstruir e repercutir sua voz, legitima seu espaço hoje, quando a morte de fato é chegada para o corpo.Ao escrever a morte do homem, seja de corpo, seja de voz, a poesia de Gullar escreve a vida e o país. E, por meio da poesia, consegue deixar viva a memória, o que inclui a miséria vivida, saindo do corpo e entrando para a História.

\section{Referências}

AUERBACH, Erich. Germinie Lacerteux. In: Mimesis. São Paulo: Perspectiva, 1976.

BAKHTIN, Mikhail. Marxismo e filosofia da linguagem. São Paulo: Hucitec, 1979.

BAUDELAIRE, Charles. Les fleurs du mal. Paris: Gallimard, 1964.

BAUMAN, Zygmunt. Identidade. Rio de Janeiro: Zahar, 2005.

BENJAMIN, Walter. O autor como produtor. In: . Magia e técnica, arte e política. São Paulo: Brasiliense, 1987.

BOSI, Alfredo. Ferreira Gullar: a poesia participante. In: BOSI, Alfredo. História concisa da Literatura Brasileira. São Paulo: Cultrix, 2002.

BOSI, Alfredo. Roteiro do poeta Ferreira Gullar. In: Céu, inferno. São Paulo: Duas cidades; Ed. 34, 2003, p. 171-85.

CANDIDO, Antonio. A literatura e a formação do homem. Remate de Males. Campinas: Editora Unicamp, 1999.

CANDIDO, Antonio. Literatura e Sociedade. São Paulo: Publifolha, 2000.

GULLAR, Ferreira. Poema Sujo. Rio de Janeiro: José Olympio, 2013. 
GULLAR, Ferreira. Melhores Poemas. São Paulo: Global, 2004.

HALL, Stuart. Da Diáspora: identidades e mediações culturais. Belo Horizonte: Editora UFMG, 2006.

LAFETÁ, João Luiz. A dimensão da noite e outros ensaios. São Paulo: Duas Cidades/Editora $34,2004$.

WELLEK, René; WARREN, Austin. Teoria da Literatura. Coimbra: Europa-América, 1976.

\title{
Shattered reconstruction: memories of an outcast man
}

\begin{abstract}
This article, with the support of the elaborations of the Stuart Hall on Diaspora, aims to analyze the association between aesthetics and life in the exile of Ferreira Gullar, bringing to the center the poem "Poema Sujo", published in 1976. The moment of creation, which represents the search for the past, is in a period of strong tension, due to the upsurge of the sieges of Brazil, then under the military regime. In the impulse to leave a testimony of his life, believing to take advantage of the remaining time, the verses seek to reconstruct, by the poetic word, time, life and outcast space. It is observed that, in representing his trajectory by the art of the word, he writes the antagonistic History that lives. This association between Poetry and Life creates, in the case of Gullar, a configuration that reinforces the feeling coming from the diaspora, because, when revolving his life, remodels the ways of saying it as a reflection of the spirit of revolt of which it is attacked. Language strengthens the purposeful aesthetic impact, and this procedure strengthens the ideological confrontation, in a radical contrast to conservatism.
\end{abstract}

Keywords: Poem dirty. Diaspora. History. Rebellion.

Recebido em: 21 de maio de 2019.

Aceito em: 11 de junho de 2019. 